\title{
PERPUSTAKAAN UMUM
}

\author{
Tjandra Huann ${ }^{1)}$, Agustinus Sutanto ${ }^{2)}$ \\ 1) Program Studi S1 Arsitektur, Fakultas Teknik, Universitas Tarumanagara, t_huann@yahoo.com \\ 2) Program Studi S1 Arsitektur, Fakultas Teknik, Universitas Tarumanagara, afirawiniera@gmail.com
}

\begin{abstract}
Abstrak
Sebuah ruang terbuka sangatlah dibutuhkan oleh berbagai macam orang. Keterbukaan dari ruang tersebut berfungsi juga sebagai ruang "refreshment" bagi para orang - orang yang memiliki hidup yang monoton seperti pekerja. Dimana pekerja pergi bekerja pada pukul 8 pagi dan pulang pada 5 sore. Kehidupan seperti itu membuat seseorang membutuhkan sebuah ruang dimana ia dapat menyegarkan pikirannya yang Lelah. Banyaknya orang - orang yang tidak memiliki tempat untuk bersantai juga dapat membuat seseorang menjadi stres. Stres ini dapat menjalar kepada berbagai macam penyakit fisik maupun psikis. Penyakit fisik yang disebutkan ini menyangkut berbagai macam hal seperti jantung, berat badan (obesitas), dan lain - lain. Sedangkan dalam segi psikis, berbagai macam efek seperti depresi, stres kronis, dan berbagai macam gangguan psikis lainnya. Stres seperti ini dapat dikelola dengan baik saat seseorang bisa mendapatkan hiburan ataupun dukungan emosional saat bertemu dengan sanak saudara ataupun dengan teman - temannya. Tetapi, hal ini berbeda dengan para shift workers, dimana para pekerja malam tidak memiliki waktu yang cukup untuk bersosialisasi. Oleh karena itu, dibuatlah sebuah perpustakaan umum dengan tujuan rekreasi dan juga dengan konsep Third Place. Rekreasi disini memiliki artian dimana orang - orang dapat bersantai setelah bekerja dan bersantai membaca buku ataupun bersantai di taman. Dengan menerapkan konsep Third Place, tempat ini bersifat gratis dan juga terbuka kepada semua orang. Keterbukaan ini diharapkan mengundang orang - orang untuk datang dan masuk ke dalam dan terjadi berbagai macam interaksi sosial.
\end{abstract}

Kata kunci: pekerja; ruang; stres; terbuka

\begin{abstract}
An open space is a need needed by many people. These open space acts as a refreshment space for people whose life is monotone, who does the $8-5$ work hours. This type of lifestyle could make people have a need for a refreshment for their tired minds. So much people don't have a place to to go after work, a place where they can refresh and relax at the same time which could lead to stress. These kind of stresses could become physical and psychic problems. Physical problems could relate to heart problems, diabetic problems, and many more. While psychic problems could involve depression, chronic stress, and many more. These kind of stresses could be managed well by getting enough entertainment or an emotional support by socializing with families and friends. But things are a bit different about shift workers, where shift workers don't have time to socialize with them. For that, a public library with a recreation purpose idea is proposed. This public library applies the concept of Third Place, where this place would be free and open to everybody and anybody. This kind of openness is expected to persuade people to come and interact with each other.
\end{abstract}

Keywords: opennes; space; stress; workers

\section{PENDAHULUAN}

Seorang manusia, memiliki banyak kebutuhan - kebutuhan hidup yang harus dipenuhi. Berbagai macam cara dilakukan manusia untuk mendapatkan berbagai macam kebutuhannya. Kebutuhan untuk makan, minum, tempat tinggal, keamanan, kenyamanan, sosialisasi, dan hingga aktualisasi diri. 
Ada sebuah teori tentang berbagai macam kebutuhan hidup manusia yang dibentuk oleh seorang psikolog humanistic, Abraham Maslow. la tidak percaya bahwa manusia yang mendorong dan ditarik oleh kekuatan mekanik, salah satu dari rangsangan dan bala bantuan (behaviorisme) atau impuls naluriah sadar (psikoanalisis). Manusia berfokus pada potensi. la percaya bahwa manusia berusaha untuk meraih potensi kemampuan terbaiknya. Manusia mulai mencari - cari batas kreativitas, dan hingga yang paling tinggi yaitu mencapai kesadaran dan kebijaksanaan. Maslow (1943) menyebutkan ini sebagai "Fully - Functioned Man", "Healthy Mind", atau "Self - Actualization." Maslow membentuk sebuah hirarki dari lima tingkat kebutuhan dasar. Dalam teori ini, manusia tidak akan memerlukan tingkat kebutuhan dasar atas saat kebutuhan dasar yang dibawah belum terpenuhi atau terpuaskan. Kebutuhan dasar Maslow adalah sebagai berikut:

\section{- Kebutuhan Fisiologis}

Kebutuhan fisiologis adalah kebutuhan mendasar biologis. Dimana seorang manusia membutuhkan oksigen, air, makanan, dan menjaga suhu tubuh agar relative konstan. Kebutuhan ini adalah kebutuhan yang paling mendasar dan juga yang paling kuat, karena tanpa adanya ini kebutuhan lain tidaklah dibutuhkan

\section{- Kebutuhan Keamanan}

Setelah kebutuhan fisiologis sudah terpenuhi secara konstan dan tidak lagi mengendalikan pikiran dan perilaku, manusia akan mulai untuk mencari sebuah kebutuhan keamanan. Biasanya, orang dewasa memiliki sedikit kesadaran akan keamanan mereka kecuali pada saat darurat ataupun pada saat disorganisasi struktur sosial (kerusuhan). Sedangkan pada anak - anak, kebutuhan ini akan lebih sering ditampilkan dan perlu diberikan kepada mereka.

- Kebutuhan Cinta, Sayang, dan Kepemilikan

Setelah kebutuhan sebelumnya, yaitu keamanan dan kesejahteraan fisiologis puas, akan muncul kebutuhan lainnya. Yaitu kebutuhan untuk cinta, kasih sayang, dan juga kepemilikian. Maslow menyatakan bahwa orang mencari kebutuhan ini untuk mengatasi perasaan seperti kesepian dan keterasingan. Hal ini melibatkan memberikan dan menerima cinta, kasih sayang, dan juga rasa memiliki.

\section{- Kebutuhan Harga Diri (Self - Esteem)}

Setelah ketiga kebutuhan sudah terpenuhi, akan muncul sebuah kebutuhan akan harga diri. Kebutuhan ini dapat menjadi dominan, dan melibatkan harga diri seseorang dalam (contohnya) mendapatkan penghargaan dari orang lain. Setelah terpenuhi, seseorang akan merasa percaya diri dan berharga karena merasa sudah menjadi seseorang yang berguna di dunia. Sebaliknya, saat seseorang tidak mendapatkan kebutuhan ini, dapat muncul perasaan frustasi, dimana seseorang akan merasa rendah, lemah, tak berdaya, dan tidak berharga.

\section{- Kebutuhan Aktualisasi Diri}

Setelah 4 kebutuhan tadi telah terpenuhi, akan muncul sebuah kebutuhan aktualisasi diri. Maslow menggambarkan aktualisasi diri sebagai keharusan seseorang untuk menjadi sesuatu yang telah ditakdirkannya. Contohnya, "musisi haruslah bermusik, seniman haruslah melukis, dan penyair harus menulis." Kebutuhan ini akan membuat seseorang terkadang gelisah, seperti berasa berada di sebuah tepi, tegang, kurangnya sesuatu. Berbeda dengan kebutuhan lainnya, saat seseorang lapar atau merasa tidak aman, akan sangat mudah untuk mengetahuinya. Sedangkan kebutuhan ini tidak semudah itu untuk diketahui. 


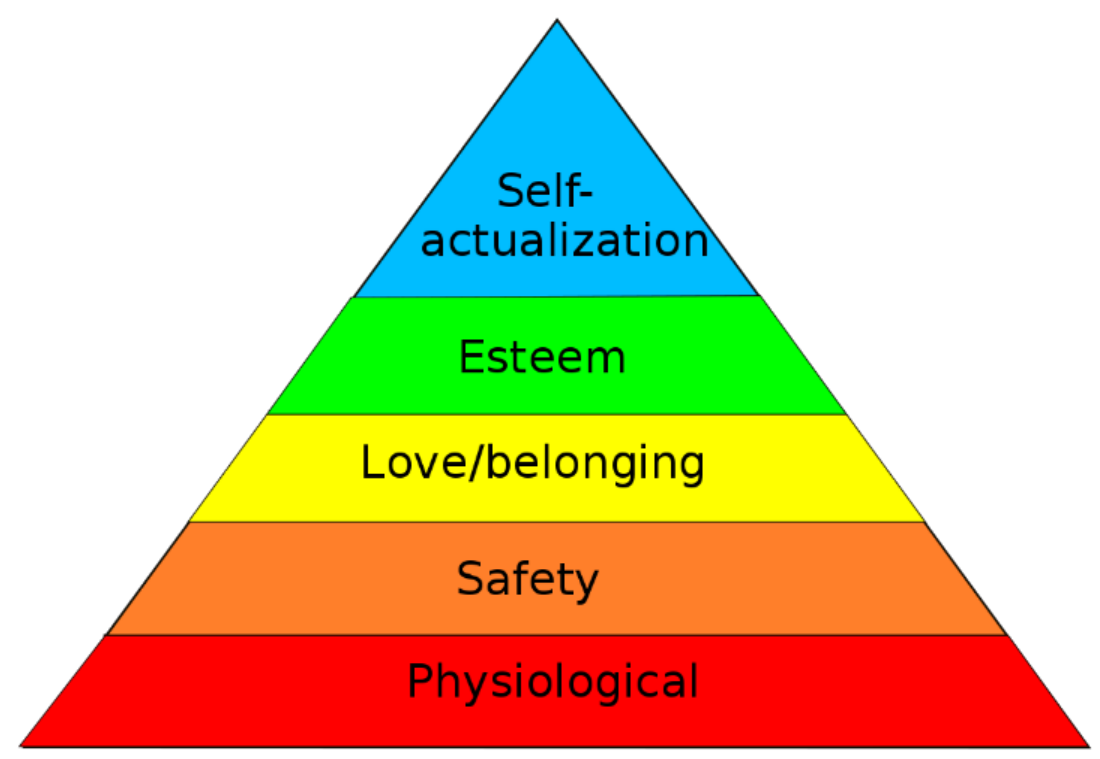

Gambar 1. Marlow's Pyramid of Needs

Sumber: images.google.com, 2019

\section{KAJIAN LITERATUR}

Tempat Ketiga. Dimana seseorang bukan di kantor ataupun berada di rumah. Tetapi sebuah tempat lain dimana seseorang dapat menghabiskan waktu dengan nyaman dan tanpa gangguan. Sebuah tempat informal dimana seseorang dapat berinteraksi dengan orang lain dan bersenang - senang. Tempat ini melayani masyarakat dari kalangan manapun dan kapanpun sebagai sebuah tempat berkumpul public yang informal.

Berdasarkan buku The Great Good Place karya Oldenburg (1999) menyebutkan bahwa tempat - tempat seperti Bar / Pub merupakan Third Place. Dimana tempat itu terdapat banyaknya komunikasi / interaksi antar pemilik bar, pengunjung dan juga pelanggan regulernya. Di tempat ini, banyak terjadi pertukaran informasi, banyak juga terjadi pertemuan - pertemuan antara orang orang baru. Tempat ini menjadi sebuah 'pelarian' bagi orang orang yang tiba tiba merasakan kebosanan dan kesepian. Sebuah lingkungan dimana semua orang mengenal satu sama lain. Walaupun tidak bisa dibilang bahwa semua orang akan menyukai satu sama lain, tetapi mengenal satu sama lain tetaplah penting. Begitu banyak orang yang bercampur scecara umum dan masing masing belajar untuk bisa hidup tidak peduli bagaimana perasaan satu sama lain. Secara umum, Third Place adalah sebuah tempat Mixer.

Fungsi utama dari Third Place ini adalah komunikasi. Antara satu manusia dengan manusia lainnya. Lalu nantinya akan membentuk suatu komunitas. Lalu, Third Place juga dapat mengurangi (Leveing - Out) adanya strata sosial, dan bagaimana seseorang melihat strata sosial lainnya. Karena di Third Place, tidak ada strata sosial sama sekali, semua orang menjadi manusia yang sama dan sederajat. Fungsi utama yang paling mulia dari sebuah Third Place adalah penyatuan antara masyarakat muda dan tua dalam sebuah lingkungan yang nyaman. Karena sekarang ini terjadinya ketegangan antara masyarakat yang lebih tua dan muda. Banyaknya perbedaan pendapat antara norma norma dan meningkatnya kekerasan Sekarang ini.

Third Place meningkatkan nilai sosial yang berada di dalam diri manusia. Dengan meningkatkan komunikasi / interaksi antara sesama, muncullah sebuah kepedulian antara satu sama lain. Saat kepedulian ini muncul, mereka akan mulai menjaga satu sama lain. Hal ini jauh lebih baik dibandingkan dengan sistem kesehatan pemerintah. Karena hal ini didasarkan kepedulian sesama. Para langganan dari Third Place akan menjaga satu sama lain, dan akan melakukan hal hal yang sama kepada sesama. 


\section{Karakteristik sebuah Third Place}

Ada beberapa ketentuan yang harus dipenuhi agar sebuah tempat dapat dikatakan sebagai sebuah Third Place yaitu:

- Mendukung inkulisivitas dan ekualitas

- Dipenuhi oleh berbagai macam orang asing

- Merupakan sebuah ruang yang dapat ditembus dari mana saja dan oleh siapa saja

- Sebuah tempat untuk pertukaran informasi

- Fleksibel dalam programming dan juga bagi pengguna untuk menempati ruang

- Kontekstual dalam menjawab berbagai macam kebutuhan manusianya dan memiliki sebuah identitas.

Menurut buku The Great Good Place karya Oldenburg (1999), disebutkan bahwa ada berbagai macam karakteristik dalam sebuah Third Place yaitu:

\section{Lokasi Third Place haruslah netral}

Lokasi dari Third Place itu haruslah merupakan tempat yang netral, harus dapat bisa diakses oleh siapapun dan kapanpun, agar dapat terjadi komunikasi dan interaksi yang informal dan bisa terjadinya relaksasi.

\section{Third Place sebagai sebuah Leveler}

Third Place berfungsi sebagai sebuah Leveler. Leveler adalah sesuatu yang dapat menghilangkan segala jenis perbedaan posisi, tingkatan, jabatan, dan lain lainnya. Hal ini mengakibatkan adanya kesederajatan antar individual. Tidak ada perbedaan strata sosial ataupun perbedaan kekuatan ekonomi.

\section{Percakapan merupakan aktivitas utama}

Third Place menyediakan sebuah tempat netral dimana percakapan dapat terjadi. Mengapa percakapan? Karena kebutuhan sosial manusia dan juga tujuan utama dari Third Place itu sendiri merupakan sosialisasi antara manusia yang kian lama mulai berkurang.

Percakapan dalam dunia sosial juga dapat digantikan dengan permainan. Seperti Gin Rummy di inggris ataupun permainan kartu lainnya yang simple dan dapat menstimulasikan pembicaraan. Tetapi, Video Games tidak dianggap sebagai pengganti yang baik, maupun ruang kecil dimana orang duduk dan bermain board games. Yang terpenting adalah dalam sebuah permainan ini bukan kemampuan dari seseorang tapi bagaimana permainan itu ditanggapi oleh orang orang.

Penonton akan merasa bosan dengan orang yang lebih lihai dalam permainan tetapi tidak dapat mendramatisir permainan itu. Penonton akan lebih merasa tertarik pada pemain yang tidak lihai tapi mampu dalam membuat suasana permainan itu menjadi seru.

\section{Aksesibilitas dan Akomodasi}

Third Place terbaik adalah tempat dimana seseorang dapat datang kapan saja dan hampir pasti bertemu dengan seseorang kenalan ataupun teman. Dimana tempat ini ada untuk siapapun saat sedang kesepian ataupun kebosanan. Third Place juga harus memiliki jam aktif yang Panjang agar dapat mengakomodir semua orang. Tergantung dari peraturan yang berlaku. Third Place harus dapat melayani kebutuhan orang - orang untuk santai kapan pun.

Kebanyakan orang yang datang ke Third Place tidak memiliki tujuan, rencana, ataupun aktivitas yang ingin dilakukan disana. Lokasi Third Place pun juga tidak bisa terlalu jauh dari tempat tinggal seseorang karena aksesnya yang susah dan kemungkinan orang tersebut untuk tidak tahu jalan. 


\section{The Regulars.}

Sebuah Third Place itu hanyalah sebuah ruang yang menyediakan pelayanan dan konsumsi. Daya Tarik dari third place itu sendiri adalah Regulars (atau yang disebut dengan 'langganan'). Langganan disini merupakan orang - orang yang berada di Third Place itu secara terjadwal ataupun sangat sering berada di Third Place itu. Para langganan inilah yang memberikan Third Place sebuah karakter. Merekalah yang memberikan kesan bahwa tempat tersebut ramah.

Para Langganan ini juga awalnya bukan siapa - siapa. Tetapi mereka sering datang dan sering berinteraksi disana. Dari situ, orang ini lama kelamaan akan menjadi langganan juga. Perlahan - lahan, langganan ini akan membawa orang orang asing dan mereka pun ikut berbaur. Mereka yang sering datang dan sering berbaur akan menjadi langganan.

Tetapi bagaimana dengan orang asing yang hanya datang sendiri? Jawabannya kurang lebih sama, dengan pihak dari langganan tahu bahwa orang ini dapat diajak berbicara dan berinteraksi, ia akan menjadi langganan secara perlahan - lahan. Inti dari munculnya langganan ini adalah kepercayaan akan satu sama lain.

\section{Simple/Polos (A Low Profile)}

Tempat Third Place merupakan tempat yang simple dan polos. Prinsip utama dari Third Place adalah 'homeliness'. Dimana pengunjung dapat merasakan kenyamanan berada di dalam Third Place itu. Tempat yang terlihat agak kurang menarik akan melindungi tempat itu dari banyaknya pengunjung yang hanya datang sesekali.

Alasan lainnya mengapa Third Place polos/simple adalah untuk menghilangkan pretensi. Dengan tidak menggunakan dekorasi yang terlalu cantik ataupun mewah, agar dapat menghilangkan pretensi sosial. Hal ini juga berhubungan dengan cara berpakaian seseorang. Tidak adanya norma berpakaian (dresscode), dengan ini pengunjung dapat langsung datang ke Third Place tanpa perlu memperhatikan pakaian.

Saat munculnya keramaian interior, akan muncul kesadaran diri seseorang, akan muncul rasa malu seseorang, dan ada yang akan merasakan pretensi sosial.

\section{A Playful Mood}

Kesenangan, Keceriaan adalah mood dari Third Place. Terkadang, keceriaan ini telrihat secara jelas, saat sebuah kelompok sedang tertawa. Dan beberapa waktu lainnya tidak terlalu terlihat. Dalam sebuah Third Place, Kesenangan dan Penerimaan merupakan hal utama. Bukan kecemasan dan pengasingan. Tempat ini menjadi makin hangat begitu seseorang makin mengenal dan makin dekat dengannya.

Tanda yang tidak dapat dipungkiri saat seseorang sudah diterima Bersama para langganan bukan saat mereka ditanggapi secara serius, tetapi saat mereka terlibat dengan perkumpulan mereka. Perasaan akan kebersamaan, perasaan akan membagi sesuatu yang penting dengan dunia ataupun menolak norma biasa dunia. Hal hal seperti ini yang merupakan inti dari mood Third Place. Secara contoh adalah saat seseorang menjalani acara sosial yang seharusnya menjadi membosankan, tetapi sebuah waktu yang ajaib terjadi. Seseorang itu bertahan lebih lama dari yang seharusnya karena dia menikmati waktu ini dan tidak mau cepat - cepat pulang. Waktu ajaib ini memberikan sugesti kepada orang - orang untuk mau melakukan hal seperti ini lagi. Third Place ada karena keinginan manusia untuk melakukan hal hal seperti ini lagi.

\section{Rumah Yang Jauh dari Rumah}

Third Place sering kali dibandingkan dengan rumah (home) dan seringkali Third Place merupkana pilihan terbaik. Bukan karena perbedaannya, tetapi karena persamaannya. Menurut kamus Merriam-Webster, Rumah (Home) adalah "A Congenial Environment" yang berarti sebuah lingkungan yang cocok. Sebuah rumah, bisa ada tanpa adanya sebuah lingkungan yang cocok. Tetapi, Third Place tidak bisa. 
Menurut psikologis David Seamon, ada 5 kriteria dimana "Rumah yang jauh dari rumah" dapat diterjemahkan.

1. Keterikatan

Sebuah rumah mengikat kita. Memaksa kehadiran kita, bagaimana pun itu. Saat seseorang pulang dari kantor, ia akan pulang ke rumah. Sebuah rumah atau kantor memaksa kehadiran kita. Tetapi tidak dengan Third Place. Third Place tidak bisa memaksa kehadiran yang terus menerus seperti itu. Third Place lebih memiliki kebebasan untuk para penggunanya.

2. Kepemilikan

Orang - orang yang sudah menjadi langganan sebuah Third Place akan berpikir dan menggunakan kata - kata seakan akan tempat itu miliknya. Contoh: "Ayo kita pergi ke café kita". Disini dimaksudkan bukan café dari orang tersebut tetapi café dimana mereka bisa bersantai dan berekspresi. Seakan - akan café tersebut milik mereka.

Berbeda dengan sebuah rumah, saat teman - teman berkumpul dan bermain, walaupun sebaik - baiknya tuan rumah, pasti ada perasaan seperti tidak seharusnya berada disitu.

3. Restorasi / Regenerasi

Rumah merupakan tempat seseorang merestorasi atau beristirahat. Tetapi jika kita berbicara tentang restorasi jiwa, Third Place merupakan tempat yang terbaik. Banyaknya orang yang berkata bahwa lebih nyaman sekali - sekali pergi keluar Bersama teman temannya jauh dari keluarga dan rumahnya

4. Perasaan Kebebeasan

Ekspresi, kebebasan berbicara, bercanda, tertawa, dan perasaan Bersatu dengan lingkungannya. Pada Third Place, orang - orang bebas untuk melakukan hal hal seperti ini, tanpa adanya larangan.

5. Kehangatan

Kehangatan ini muncul dari rasa pertemanan, rasa kenyamanan, keberadaan dengan teman teman lainnya. Digabung dengan rasa rasa keceriaan dan perasaan senangnya bisa menikmati hidup. Rumah bisa hidup tanpa adanya kehangatan, sedangkan Third Place tidak bisa.

\section{Fungsi (Keuntungan) Third Place}

Dalam buku The Great Good Place Ray Oldenburg (1999), dijelaskan bahwa Third Place memiliki berbagai macam keuntungan bagi para pengunjungnya, yaitu Novelty, Perspective, Spiritual Tonic, Friends.

Novelty berarti sebuah kebaruan, sebuah pembaharuan, Third Place menampung banyak sekali orang orang yang beragam. Dalam hal ini, orang - orang baru untuk seseorang. Dengan adanya orang orang baru, hal ini berarti banyaknya hal baru yang dapat terjadi, banyak sekali topik pembicaraan yang unik. Tidak seperti halnya jika berada di rumah, dimana hal yang dibicarakan selalu sama dan tidak terlalu terkesan bervariasi. Dan juga dengan banyaknya orang disana, banyak sekali kemungkinan untuk hal hal baru terjadi. Setiap kedatangan seseorang akan berbeda setiap saatnya, ada kemungkinan untuk bertemu orang baru dan bertemu teman - teman yang tidak terduga.

Perspective. Apa yang ingin dijelaskan disini adalah kontak antar manusia. Pemikiran manusia sangat mudah berubah. Saat seseorang ditinggal sendiri, pikiran orang tersebut perlahan lahan akan dengan mudah berubah menjadi irasional. Khususnya orang tua. Berbeda dengan anak muda, orang tua akan lebih sering berkomunikasi dengan orang - orang di sekitarnya karena tidak bisa selektif dalam berinteraksi. Pikiran membutuhkan asupan kontak (komunikasi) dengan manusia lainnya seperti tubuh membutuhkan gizi. Third Place disini 
berkontribusi dalam memberi perspektif yang sehat (pikiran yang sehat) dengan menggabungkan berbagai macam pemikiran dan kebijakan orang - orang yang beragam.

Spiritual Tonic. Third Place menjadi tempat yang dapat membangkitkan semangat seseorang walaupun sedang buruk. Interaksi Third Place memiliki energi untuk "membangkitkan semangat seseorang."

Friends. Orang orang yang dikenal di sebuah Third Place memiliki banyak keragaman yang berbeda - beda, maka dari itu, hal inilah yang membuat pertemanan di sebuah Third Place menjadi spesial. Banyaknya interaksi dengan orang orang yang berbeda latar belakang, dan memiliki pengalaman yang berbeda.

\section{Perkembangan dari ICT (Information and Communication Technology)}

Tetapi, seiring berjalannya waktu, teknologi pun makin berkembang. Ray Oldenburg mencetuskan beberapa karakteristik ini pada tahun 90an, dimana waktu itu teknologi informasi dan komunikasi belum secanggih sekarang. Ada sebuah penelitian yang dilakukan oleh beberapa orang professor dan mahasiswa. Penelitian ini mempertanyakan tentang beberapa karakteristik dari Third Place itu dan bagaimana perilaku dari pengguna dari Third Place itu sendiri. Oldenburg (2009) berkata bahwa ICT (Information and Communication Technology) itu "dehumanizing", "pixelating." Yang berarti tidak manusiawi karena tidak ada kontak secara langsung (physical contact)

Tetapi penelitian ini berkata bahwa perkembangan zaman tidak dapat dipungkiri dan harus diintegrasikan kedalam teori Third Place itu sendiri. Seperti contohnya, bahwa dalam sebuah café tidak mungkin ada 1 orang pun yang tidak melakukan aktivitas digital seperti membuka media sosial, berbicara dengan orang lain melalui aplikasi chatting. Perkembangan ICT harus dapat dinaungi dan dapat dipraktikan kedalam Third Place ini. Dengan adanya ICT, banyak teori dari Oldenburg yang dapat dikaji ulang.

Neutral Ground. Tempat dimana orang - orang dapat bersosialiasi di Third Place dan menyediakan tempat netral dimana berbagai macam orang dengan pandangan yang berbeda dapat merasa diterima. Walaupun, hal ini benar, tetapi menurut penelitian ini, terbagi berbagai macam peran seperti 'pengamat' dan 'yang diamati', dan hal ini pun bisa menjadi sebuah perbincangan.

Leveler. Tempat dimana seluruh ketidak adilan, strata sosial dan sebagainya dibuang dan tidak memiliki pengaruh apapun di tempat itu. Menurut penelitian ini, hal tersebut memang masih benar dalam segi ruang fisik. Tetapi, banyak tempat yang tidak menawarkan akses internet kepada orang - orang sehingga tidak semua orang memiliki akses yang sama.

Conversation. Tempat dimana perbincangan adalah aktivitas utama. Pada akhirnya, setelah munculnya ICT, bukan hanya perbincangan yang menjadi aktivitas pertama, tetapi mengamati orang lain, bermain dan menikmati board games juga menjadi sebuah aktivitas utama. Dan juga berbagai macam interaksi sosial secara online. Jika dikatakan, interaksi sosial menjadi kata yang lebih tepat dibandingkan dengan perbincangan.

Accessibility and accommodation. Tempat yang mudah diakses secara geografis dan sosial. Dalam segi fisik, hal ini benar. Tetapi, mirip dengan permasalahan di Leveler, tidak semua tempat menyediakan akses internet sehingga membatasi akses kepada sisi online yang diiklankan.

Regulars. Regulars memberikan bentuk dan nada pada sebuah tempat. Tetapi, para staf yang bekerja dan juga tema dari sebuah tempat dapat menjadi sebuah nada dari tempat itu sendiri. 
Low Profile. Third Place memiliki gaya yang simple, desain yang simple agar memberikan pengunjung kenyamanan dan relaksasi. Tetapi, dalam penelitian, ada tempat yang tidak typical, tetapi terhadap beberapa komunitas, tempat tersebut typical. Dan juga, banyak Third Place mengiklankan kehadiran mereka dia situs online. Hal ini cukup bertentangan dengan prinsip low profile.

The mood is playful. Perbincangan di Third Place merupakan perbincangan ringan. Tetapi, ada berbagai macam mood dan juga berbagai macam level mood. Beberapa Third Place juga tidak menyediakan berbagai aktivitas ataupun hal pendukung untuk memberikan mood playful seperti pada sebuah café board games.

A home away from home. Third Place seharusnya memberikan lingkungan luar rumah selagi memberikan perasaan yang sama saat berada di rumah. Walaupun banyak tempat yang memberikan kesan seperti ini, tetapi, dengan berkembangnya ICT yang merubah Third Place sekarang, saat tempat tersebut memperhatikan pengunjung dan vice versa, terkadang hal ini tidak diperbolehkan seperti pengambilan gambar ataupun video. Hal ini memberikan kesan yang jauh dari sebuah kesan dir umah. Dan bahkan sekarang, dengan perkembangan ICT, tempat tempat Third Place dapat terjadi secara online.

Lalu ada juga 3 poin yang dicetuskan oleh para peneliti ini yaitu:

Discovering a third place in advance. Dengan berkembangnya ICT, pengunjung dapat melihat kedalam sebuah Third Place tanpa harus memasukinya secara fisik.

Declaring type of supported social activity. Third place sekarang dapat menyatakan dan mengiklankan tipe aktivitas sosial yang mereka dukung dan sediakan. Contoh: board game café

Extending engagement with/within a third place. Sekarang orang - orang dapat berinteraksi lebih jauh dengan sebuah Third Place. Contohnya seperti memberikan like di Facebook.

Saat sebuah tempat tidak memiliki infrastruktur yang baik, banyak orang yang akan terkena akibatnya, seperti kekurangan moda transportasi, tidak dapat berpergian jauh. Oleh karena itu, banyak orang yang mencari hiburan ataupun tempat untuk bersenang - senang yang dekat dengan tempat tinggalnya.

\section{METODE}

Metode perancangan yang akan digunakan pada proyek ini mengacu buku Architectural Programming: Information Management for Design karya Donna P. Duerk (1993) dikatakan bahwa ada 4 kriteria yang harus dipenuhi dan yang harus diterapkan pada perancangan, yaitu :

a. Care in the community

b. Design for domesticity

c. Social valorization

d. Integrated with Nature

Konsep - konsep tersebut merupakan panduan untuk membentuk sebuah desain yagn berdasarkan poin poin tersebut. Untuk ekspolorasi desain yang akan diterapkan berdasarkan oleh teori kepada objek rancang yaitu:

a. Care in the community (Rancangan harus dapat mendorong dan mengakomodasi terjadinya interaksi dan sosialisasi)

- Sirkulasi terpusat untuk memperbanyak pertemuan - pertemuan antara para pnegguna dari Third Place

- Membuka banyaknya ruang - ruang terbuka dan ruang bersama agar memperbanyak pertemuan - pertemuan.dan juga berbagai macam interaksi sosial. 
b. Design for domesticity (Rancangan harus dapat menciptakan dan memberi suasana seperti di rumah)

- Tempat yang tidak memiliki aturan aturan yang ketat sehingga orang - orang bisa merasa bebas

- Menggunakan skala manusia yang sesuai agar memberi kesan ramah, bersahabat, dan menenangkan

- Penggunaan warna - warna yang hangat agar terkesan lebih bersahabat dan menenangkan

c. Social valorisation (Rancangan harus dapat menjaga privasi dan keamanan pengguna)

- Memiliki akses yang tidak banyak, jika memungkinkan hanya satu agar keamanan bisa lebih mudah diatur

- Memisahkan ruang - ruang privat jauh dari public

- Menggunakan material - material yang tembus pandang agar pengawasan dapat menjadi lebih mudah

d. Integrated with nature (Rancangan harus dapat memanfaatkan dan memaksimalkan elemen-elemen alami di tapak dan sekitarnya)

- Penggunaan elemen - elemen alami yang berada di tapak ataupun yang mudah untuk didapatkan

- Penggunaan elemen - elemen yang mendukung sustainability

- Memperbanyak tumbuh - tumbuhan

- Penggunaan material alami untuk kesan natural

\section{DISKUSI DAN HASIL}

Dari hasil diskusi dan penelitian yang dilakukan, maka hasil diskusi yang dilakukan sebagai berikut:

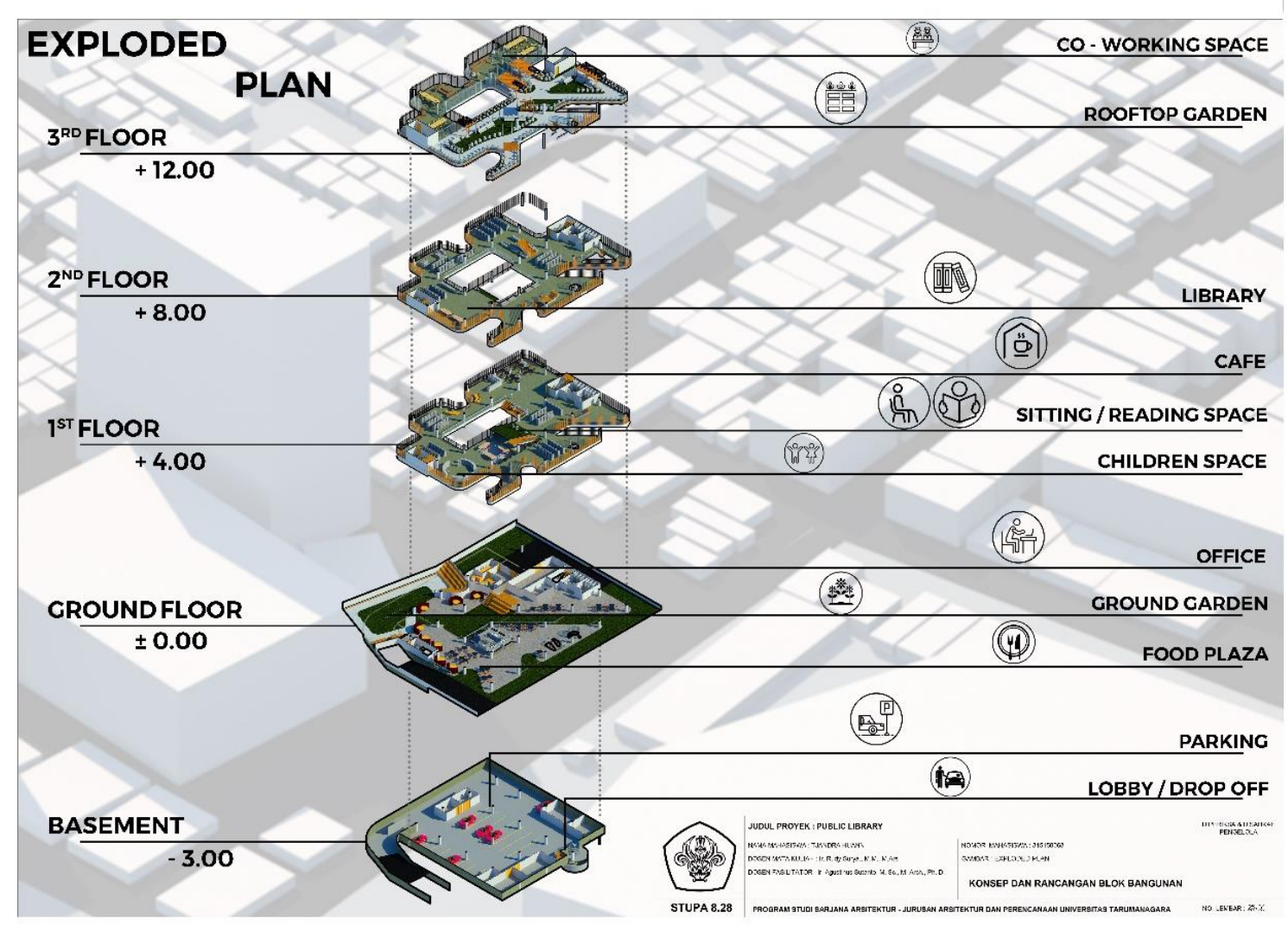

Gambar 2. Exploded Plan Sumber: Penulis, 2019 


\section{Analisis Program Kegiatan:}

- Food Plaza

Food Plaza merupakan sebuah program yang diaplikasikan terhadap bangunan guna untuk menganggapi konteks karakter kawasan di mangga besar, dimana pada siang hari malam hari terdapat banyak tempat yang berjualan makanan khususnya pada malam hari, dimana banyak tenda biru yang membuka usaha mereka. Oleh karena itu, dibuatlah fungsi Food Plaza agar bangunan dapat membaur secara kontekstual.

\section{- Public Library}

Fungsi utama bangunan dimana perpustakaan ini menjadi sebuah Third Place dan menjadi sebuah tempat dimana orang - orang dapat datang untuk bersantai dan juga bersosialisasi. Konsep pada public library ini dibuat seterbuka mungkin secara akses tetapi juga memikirkan privasi dan juga ruang - ruang pada perpustakaan tersebut. Fungsi ini tidak dipungut biaya sehingga permeabilitas dari tempat ini sangat tinggi dan diharapkan banyak orang yang akan datang berkunjung dan berinteraksi.

\section{- Co-Working Space}

Sebuah fungsi penunjang dimana seseorang dapat datang dan bekerja di dalam co working space tersebut. Fungsi ini hanya dapat diakses melalui perpustakaan sehingga akses yang terbatas ini memiliki tingkat keamanan yang lebih.

Program yang ditawarkan disini adalah program perpustakaan umum, dimana sebuah perpustakaan umum dibutuhkan oleh orang - orang yang membutuhkan sebuah tempat untuk bersantai tetapi tidak memiliki tempat yang sesuai untuk bersantai. Tempat ini akan memiliki target - target yang berupa orang - orang yang membutuhkan tempat dan tanpa memerlukan biaya sedikitpun untuk menikmati sebuah tempat untuk bersantai. Tempat ini menjawab konteks Third Place, dimana sebuah Third Place memerlukan berbagai karakter seperti:

\section{- $\quad$ Neutral Ground}

Tempat ini tidak memiliki batasan untuk siapapun dari berbagai latar belakang ataupun status untuk didatangi. Semua orang yang ingin masuk dan beraktivitas dipersilahkan untuk datang

\section{- $\quad$ Low Profile}

Perpustakaan umum ini tidak memiliki desain arsitektur yang memiliki karakter yang mewah ataupun mencolok, sehingga tempat ini memiliki karakter yang humble. Karakter ini didesain sedemikian rupa agar tidak mengintimidasi seseorang untuk masuk.

\section{- Leveler}

Tempat ini merupakan sebuah tempat dimana semua orang dapat mengaksesnya dan tidak terdapat adanya biaya, sehingga menghilangkan adanya kesan kemewahan bagi orang orang yang memiliki status yang lebih tinggi dari lainnya.

\section{KESIMPULAN DAN SARAN}

Kawasan Mangga Besar merupakan sebuah kawasan yang memiliki konteks tentang makanan dan juga berbagai kehidupan malamnya yang kurang baik didengar. Oleh karena itu, kawasan ini memiliki kesan yang kurang baik di pikiran orang - orang. Hal ini juga menjadikan orang menjadi was - was dan sangat berhati - hati disini. Oleh karena itu, perpustakaan umum ini diciptakan untuk memberikan sebuah ruang yang aman bagi para pengunjung ataupun warga sekitar dalam mencari tempat untuk bersantai dan menghabiskan waktu dengan tenang tanpa perlu khawatir. 
Tema Third Place sangat cocok pada permasalahan yang muncul di kawasan ini. Dengan Third Place ini, kawasan Mangga Besar diharapkan akan perlahan berubah di pikiran masyarakat bahwa kawasan ini bukanlah sebuah kawasan yang memiliki kesan yang kurang baik tetapi sebuah kawasan yang menarik dan aman.

Desain arsitektur dari bangunan ini merupakan desain yang tidak memiliki sebuah karakter mencolok ataupun kemewahan. Bangunan ini memiliki fasad yang tebuat dari bahan kayu dan juga berbagai macam Vertical Gardens yang merupakan sebuah penyegar di kawasan Mangga Besar yang monoton dengan berbagai bagunan yang hanya terbuat dari beton dan kurangnya penghijauan di daerah ini.

\section{REFERENSI}

Duerk, D. P. (1993). Architectural Programming: Information Management for Design. New Jersey: Wiley.

Mclaren, D. dan Agyeman, J. (2015). Sharing Cities: A Case for Truly Smart and Sustainable Cities. Boston: The MIT Press.

Memarovic, N., et.al. (2014). Rethinking Third Places: Contemporary Design With Technology. Vol 10 No 3. http://ci-journal.net/index.php/ciej/article/view/1048/1116. Diakses tanggal 20 Agustus 2019.

Oldenburg, R. (1999). The Great Good Place. Boston: Da Capo Press.

Ratti, C. dan Claudel, M. (2016). The City of Tomorrow: Sensors, Networks, Hackers, and the Future of Urban Life. Connecticut: Yale University Press.

Simplypsychology.org. (2019, 20 Agustus). Maslow's Hierarchy of Needs. Diakses pada 20 Agustus 2019, dari https://www.simplypsychology.org/maslow.html 
